\title{
Clinical Supervision in Teaching Aprenticeship for Teacher Candidates at University of PGRI Madiun: An Evaluation for Model Development
}

\author{
VT Suharto ${ }^{1}$, D. Setiyadi ${ }^{2}$, EM Mursidik $^{3}$, EA Meikayanti $^{4}$ \\ ${ }^{1,4}$ Indonesian Language Education Department, Faculty of Teacher Training and Education, \\ Universitas PGRI Madiun, Indonesia \\ ${ }^{2}$ English Language Education Department, Faculty of Teacher Training and Education, \\ Universitas PGRI Madiun, Indonesia \\ ${ }^{3}$ Elementary School Teacher Education Department, Fakulty of Teacher Training and \\ Education, Universitas PGRI Madiun, Indonesia \\ E-Mail: suharto_teguh@yahoo.com
}

\begin{abstract}
The gap of real and ideal teaching practice was still evidently large among teachers at schools around Madiun. This research was used to observe the need for the Clinical Supervision, as professional assistance done by lecturers against teacher candidates to minimize the gap between ideal and real teaching practice. The analysis would be on: (1) the lecturers' understanding against the role of clinical supervision, (2) the needs for the development of clinical supervision as a part of the systematic cycle in teaching. The research was carried out in the class observation method for the lecturers of University of PGRI Madiun. The subjects of the research were lecturer advisors, students, school officials, learning events. The data were drawn by observation, interview and documentation. The analysis was carried out by constant comparative method. The results suggested that the lecturers' understanding against the clinical supervision needed to be improved, and a suggestion for the development of clinical supervision format
\end{abstract}

Keywords: Clinical Supervision; Class Action; Micro Teaching

\section{INTRODUCTION}

The quality of instruction conducted by teachers at schools was questionable, where the preliminary research showed that only $43 \%$ out of all teachers in Madiun applied the fixed and well-organized instructional design. The teacher education institution is in charge to provide professional teacher candidates who were skilful in applying the standard procedures of instruction. To be able to perform the duties, the educators should have the pedagogic and 
professional competence. Pedagogical competence is related to capabilities in designing the instructional objectives with measured indicators, material organization, method implementation, media and evaluation technique. While professional competence is weighed against their capabilities in implementing the pedagogic competence in teaching practice [1]. Veloo, Komuji and Khalid [2] have suggested "since clinical supervision is focused on the teaching quality, the evaluation towards teachers can be the catalyst in improving teachers teaching and school performance". Teachers or lecturers are the most influential against the candidates teaching practice, it is then strategic to develop candidates teaching practice through them.

Among the stages of development program of competent teacher candidates through teaching apprenticeship program, clinical supervision has become very important stage to initiate the whole program. Clinical supervision is based on the assumption that without guidance and assistance, teachers are not able to change and improve [3] Suharto [4] suggests that clinical supervision is a process of helping teachers to minimize the gap between the ideal and real teaching performance. It then serves diagnostic preview to find out hindrances which make teachers unable to perform teaching as well as expected, and then offers solutions against them.

Evidently, lecturers in charge for this early and crucial preparation do not implement this stage as properly as suggested for one and other reasons. Consequently, this essential phase of learning is not set ready for the next stage for the teacher candidates. Lecturers need to master the proper and constructive supervision strategies to enhance qualified teacher candidates. To guarantee the good supervision strategies, the lecturers must be prepared with a set of recommended techniques of supervision at the microteaching laboratory, classes and school [4]. On the other hand, Hasana [5] found out that teacher supervisors at schools did not either implement the proper supervision which ended in the lack of practical training for the students apprentice at schools. Lecturers at the campus and teachers at schools are responsible for the quality of candidates. When one or both of them do not work to their best proportion, the quality of the candidates will be sacrificed. These both problems have become the main reasons why this research is important to be carried out.

Clinical supervision strategy is chosen to be implemented for its dynamic and democratic matter in developing the teaching profession. Smith in Bulunuz, Gorsoy, Kenser Goktalay and Salihoglu [6] emphazises that clinical supervision is valuable because it has the potentials to bring about changes in the social interactions between stakeholders in schools. Clinical supervision can be implemented creatively one of which by class action research (with its steps: plan, do, see and reflection) being firm, collegial and learning community [4]. Supervision and class action research have similar steps, that is why action research approach is chosen to implement the clinical supervision.

This research is carried out to identify the quality of the instructional design performed by lecturers within the framework of the clinical supervision; whether they understand required procedures of instruction to prepare the professional teacher candidates. The identification is then called as needs analysis, as one step in development process [7]. Then, the results are used to design for the development of clinical supervision format which can be used as reference for any lecturer to develop his teaching. 


\section{METHOD}

The research was carried out by class observation research design for microteaching and teaching apprenticeship. The sources of data were: lecturers, students, teaching-learning events. The data collecting techniques were: in-depth interview, participant observation and documentation. Data analysis technique used was the constant comparative method. Place and time of research: University of PGRI Madiun, March up to April 2017 for the development of microteaching handbook, and September up to November for the observation in apprenticeship.

\section{RESULT AND DISCUSSION}

The nature of the clinical supervision in the micro teaching lesson that has been carried out so far.

1) Lecturer's Understanding of The Purpose of Clinical. As feedback to improve lecturer's teaching ability, clinical supervision was still needed to be improved with the average score of 4 out of 5, which lacked lecturers' awareness. As a lecturer's strategy for students' awareness and learning responsibility, clinical supervision could also be developed with the score of 4 out of 5 . As an aid to modify lecturers' teaching pattern, clinical supervision was scored 3 out of 5 . As a lecturers' way to develop students' professionalism, clinical supervision was graded medium by 3 out of 5 . As an instrument to help lecturers identify/ diagnose/ analyzed problems, clinical supervision was scored 4 out of 5 . As guidance, clinical supervision is graded 3 out of 5.

2) Lecturers' Advisors on Understanding Clinical Supervision Objectives. The clinical supervision objectives were to: modify and develop students' professionalism, motivate and develop teaching patterns, give guidance, create students awareness on their responsibility, and help lecturer identify/ diagnose/ analyze problems. Those were empirically needed to be improved.

3) Lecturer's Understanding of the Function of Clinical Supervision. The data of the function of clinical supervision were as to: analyze learning process was scored 3 out 5; develop teaching materials was graded 3 out of 5 . Those needed to be improved.

The main finding of advisors' understanding of the function of clinical supervision. Based on the data, it has been formulated the main finding that the advisors have already understood the function of clinical supervision, however, improvement is needed. as means of analyzing the teaching process was scored 3 out of 5; as the tool for developing teaching material/ curriculum was graded 3 out of 5 .

Ways to communicate in clinical supervision. advisors had develop some ways: (1) collegial/ interactive/ democratic (not evaluative, judging, authoritarian, lecturing, instruction) was scored 2 (bad) out of 5; (2) descriptive and analitical presentation was scored 3.5 out 5; (3) direct meting according to time allocation was scored 3 out of 5 ; (4) students activity in giving questions was scored 2.5 (bad) out of 5 ; (5) joint analysis between lecturer and students scored 3.5 (good) out of 5; (6) the secret talks between the two parties was scored 1.5 (bad) out of 5; (7) full of warmth and openness was scored 3.5 (good) out of 5; (8) democratic and objective feedback was scored 4.0 (good) out of 5 ; (9) the conversation is trarted by the participant and is responded by the lecturer was scored 4.0 out of 5; (10) not blaming was scored 4.0 out 0f 5; (k) the participants are free to express what they observed was scored 4.0 out of 5 . 
Material/ the data discussed in clinical supervision included: (1) disappointing aspects of teaching was scored 2.0 (bad) out of 5 ; (2) result of objective observation was scored 2.0 (bad) out of 5 ; (3) actual event in the class was scored 2.0 out of 5; (4)accuracy was scored 2.0 out of $5 ;(5)$ the eight teaching skills was scored 2.0 out of $5 ;(6)$ aspects/ objects of chronicle teaching was scored 4.0 out 5 ; (7) cycle and teaching procedure was scored 4.0 out of 5 ; (8) teaching strategy was scored 2.0 out 5 ; (9) intellectual skills in responding to the students was scored 2.0 out of $5 ;(10)$ the problem that happen in teaching and learning process was scored 3.0 out 5; (11) skills and ability that need help was scored 4.0 out 5; (12) participants' personality was scored 2.0 out of 5 ; (13) one to two teaching skills was scored 2.0 out of 5 . most of the materials of clinical supervision were scored bad which needed improvement.

The strategy invented by the advisors to improve participants' teaching skills included the way to: (1) help participant find the solution for improvement was scored 4.0 out of 5 ; (2) help participants to do self-analysis was scored 4.0 out 5; (3) "tut wuryhandayani" (facilitators) was scored 4.0 out 5 ; (4) "the self-drive of the participants to improve was scored 4.0 out of 5; (5) through systematic cycles in class action-based was scored 2.0 out 0 f 5 .

Advisors' role in clinical supervision covered: (1) as supervisors was scored 3.5 out 5 ; (2) as colleague was scored 3.5 out of 5 ; (3) as analyzer was scored 3.0 out 5.

Instruments used in clinical supervision included: (1)instruments based on agreement was scored 2.0 out of 5 ; (2) video recording was scored 3.0 out of 5.

Initial stage before observation and clinical supervision included activities as: (1) initial discussion done in the open place, intimate, relax and open for 20-39 minutes was scored 3.0 out of $5 ;(2)$ create thrust of the participants toward supervision to ensure the participant was scored 2.0 out 5; (3) select, and determine the technique, rules, as well as instrument of the observation was scored 2.0 out of 5 ; (4) identify and clarify the lesson plan was scored 3.0 out 5.

The observation phase in clinical supervision covered: (1) identify the order of the practice was scored 2.0 out 5 ; (2) carry out the observation according to the instrument set was scored 3.5 out of 5 .

Feedback phase (reflection) in clinical supervision included: (1) asking the participants' feeling was scored 1.0 out 5 ; (2) together analyzed learning purposes was scored 2.5 out of 5; (3) together analyzed the target skills was scored 2.5 out of 5; (4) asking participant's feelings was scored 1.0 out of 5 ; (5) conclude the result was scored 3.5 ; (6) encourage participants to improve was scored 4.0 out of 5 .

Table 1: Summary table of Results

\begin{tabular}{|c|c|c|c|c|}
\hline No & Score & Freq & Meaning & Total aspect \\
\hline 1 & 1 & 2 & Very concerning, however, the frequency is small & 33 Bad aspect \\
\hline 2 & 1,5 & 1 & $\begin{array}{c}\text { Very concerning, however, the frequency is very } \\
\text { small }\end{array}$ & \\
\hline 3 & 2 & 14 & Very concerning and with great frequency & \\
\hline 4 & 2,5 & 4 & Very concerning with small frequency & \\
\hline 5 & 3 & 12 & Concerning and with great number of frequency & \\
\hline 6 & 3,5 & 7 & $\begin{array}{c}\text { The condition is quite good and with great } \\
\text { frequency }\end{array}$ & $\begin{array}{l}21 \text { Good } \\
\text { aspect }\end{array}$ \\
\hline 7 & 4 & 14 & The condition is good with good frequency & \\
\hline
\end{tabular}




\section{CONCLUSION}

1. The finding showed that the frequency under 3,5 was ranked as the most number, therefore, it could be concluded that generally the clinical supervision still needed to be developed to improve the quality of teacher candidates' professionalism in FKIP University of PGRI Madiun.

2. The reason why the new model of Clinical Supervision was needed in Micro Teaching was that the real practice of micro teaching was not ideally performed by Advisors. Based on the table, the 33 out of 45 aspects were in bad condition and only 21 aspects were in a good conditions. Based on the main finding, it was decided that clinical supervision really needed to be developed. Whether it was seen from the advisors' understanding of the purpose and function of the clinical supervision, or the communication ways, materials or data discussions, improvement's strategy of the participants, lecturers, observations' instrument or procedures of clinical supervision.

\section{REFERENCES}

[1] Sudjana and Nana, Dasar-dasar Proses Belajar Mengajar. Bandung: Sinar Baru, 2000 .

[2] Veloo, Arsaythamby, and R. K. Marry Macdalena A Komuji, "The Effects of Clinical Supervision on the Teaching Performance of Secondary Scholl Teachers," in 3rd World Conference on Learning, Teaching and Educational Leadership, ProcediaSocial and Behavioral Sciences, 2013, p. 93.

[3] Oliva and P. F, Developing the Curriculum. Georgia Southern College. Boston: Little, Brown and Company, 1982.

[4] Suharto, Mursidik, and Chasanatun, Supervisi pada PM dan PPL IKIP PGRI Madiun (Penelitian Fundamental). Madiun: LPPM IKIP PGRI Madiun, 2015.

[5] Hashana, "Kajian Pelaksanaan PPL Tarbiyah IAIN Walisongo Semarang," J. Cendekia, vol. 12, no. 2, 2014.

[6] E. Gursoy, J. Kesner, and U. Salihoglu, "Clinical Supervision Model in Teaching Practice: Does it Make a Difference in Supervisors' Performance?," Aust. J. Teach. Educ., pp. 61-76, Nov. 2016.

[7] Setiyadi and Dwi, The English for Midwifery Textbook Development by Contextual Teaching and Learning for the Widwifery Study Program, Ministery of Halth, throughout East Java. Surakarta: Universitas Sebelas Maret press, 2016. 